\title{
TINGKAT KETERGANTUNGAN, KOMPLEKSITAS PEMERINTAH, DAN TINGKAT PENGUNGKAPAN LAPORAN KEUANGAN PEMERINTAH DAERAH
}

\author{
Tiara Pandansari \\ Fakultas Ekonomi dan Bisnis, Universitas Muhammadiyah Purwokerto \\ tiarapandansari@gmail.com
}

\begin{abstract}
This research aims to measure the disclosure level of local governments' financial reports in Central Java Province. More importantly, we also investigate factors associated with the disclosure level. We measure the disclosure level using the Modified LGA Index. Meanwhile we use the local government' dependence and government complexity as the independent variables. Using purposive sampling method, this research generates 32 local governments (districts/ municipals) as the final sample. The descriptive analysis suggests that the average value of the disclosure level is $58.46 \%$. Meanwhile, local governments' dependence on general allocation funds (DAU) and shared revenue funds (DBH) affect the disclosure level. However, we do not find significant effect between local governments' dependence on special allocation funds (DAK) and government complexity on the disclosure level.
\end{abstract}

Keywords: Disclosure Level, Size, local governments' dependence, government complexity

\begin{abstract}
ABSTRAK
Penelitian ini bertujuan untuk mengukur tingkat pengungkapan dalam laporan keuangan pemerintah daerah di Jawa Tengah, serta menguji dan menganalisis faktorfaktor yang mempengaruhinya. Tingkat pengungkapan diukur dengan menggunakan Modified LGA Index, sedangkan sebagai variabel bebas yang digunakan adalah tingkat ketergantungan daerah, dan kompleksitas pemerintahan. Sampel penelitian ini dipilih menggunakan purposive sampling method, sehingga diperoleh ukuran sampel yaitu 32 laporan keuangan pemerintah daerah. Alat analisis yang digunakan adalah regresi linear berganda. Hasil penelitian ini menunjukkan bahwa terdapat perbedaan tingkat pengungkapan pada masing-masing sampel. Rata-rata nilai pengungkapan sebesar 58,46 persen. Penelitian ini juga menunjukkan bahwa tingkat ketergantungan terhadap Dana Alokasi Umum dan tingkat ketergantungan terhadap Dana Bagi Hasil berpengaruh terhadap tingkat pengungkapan, tingkat ketergantungan terhadap Dana Alokasi Khusus, dan kompleksitas pemerintah tidak berpengaruh terhadap tingkat pengungkapan dalam laporan keuangan pemerintah daerah.
\end{abstract}

Kata Kunci: Tingkat Pengungkapan, Ukuran Pemerintah Daerah, Tingkat Ketergantungan Daerah, Kompleksitas Pemerintah. 


\section{PENDAHULUAN}

Reformasi sektor publik di Indonesia telah dilakukan di berbagai sektor pemerintah, tidak terkecuali sektor ekonomi dan keuangan. Di sektor ekonomi kita ingin beralih dari sistem perencanaan terpusat kepada sistem yang terdesentralisasi dengan disahkannya perubahan terakhir peraturan perundangan tentang pemerintah daerah yaitu UU Nomor 32 tahun 2004. Dalam sektor pengelolaan keuangan, pemerintah melakukan reformasi dengan mengeluarkan Undang-Undang Nomor 17 Tahun 2003 tentang Keuangan Negara yang mensyaratkan bentuk dan isi laporan pertanggungjawaban pelaksanaan Anggaran Pendapatan dan Belanja Negara (APBN) dan Anggaran Pendapatan dan Belanja Daerah (APBD) disusun dan disajikan dengan standar akuntansi pemerintahan yang ditetapkan oleh peraturan pemerintah.

Reformasi sektor publik dianggap memiliki sifat yang lebih baik, hal ini juga memiliki beberapa kelemahan mendasar. Sebagai contoh peningkatan kinerja yang dicapai dengan mengorbankan nilai kualitas, dan kewajaran serta mengubah orientasi dasar akuntabilitas yang luas menjadi hanya akuntabilitas keuangan saja (Mulgan 2002; Haning 2003). Peraturan dan perundang-undangan yang telah dibuat berkaitan dengan akuntabilitas telah banyak disusun, namun akuntabilitas pemerintah masih belum menunjukkan perbaikan yang signifikan.

Berdasarkan data Badan Pemeriksa Keuangan dan Pembangunan pada website BPK (www.bpk.go.id), disajikan informasi bahwa akuntabilitas pelaporan keuangan negara masih memerlukan perbaikan. Hal ini ditandai dengan masih belum diperolehnya opini Wajar Tanpa Pengecualian (WTP) dari BPK atas Laporan Keuangan Pemerintah Pusat (LKPP) Tahun 2011, demikian juga atas 20 Kementerian/Lembaga (K/L) atau 23 persen dari total K/L, serta pada hampir semua Pemerintah Daerah (Pemda), yaitu 431 Pemda atau 87 persen dari 498 Pemda yang diaudit BPK. Selain itu, berdasarkan penelitian tentang penilaian publik terhadap akuntabilitas pemerintah daerah di provinsi Jawa Tengah hasilnya menunjukkan bahwa penilaian publik terhadap akuntabilitas pemerintah daerah di provinsi Jawa Tengah masih rendah.

Penelitian mengenai pengungkapan laporan keuangan khususnya pemerintah daerah dan faktor yang mempengaruhinya penting untuk dilakukan. Hal ini dikarenakan pengungkapan dalam laporan keuangan akan menggambarkan tentang perbedaan praktik pengungkapan yang telah dilakukan oleh entitas pemerintah daerah, faktor-faktor yang mempengaruhinya, serta menggambarkan kondisi pemerintah daerah tersebut pada periode pelaporan. Selain itu, pengungkapan juga merupakan faktor penting dalam pencapaian efisiensi dan sebagai sarana akuntabilitas. Ryan, Stanley, dan Nelson (2002) menguji kualitas laporan tahunan pemerintah daerah Queensland dan faktor-faktor yang mungkin mempengaruhi tingkat kualitas pelaporan, dengan menggunakan model Local Government Accountability (LGA) Index. Secara rata-rata, kualitas pengungkapan meningkat dari 
tahun ke tahun dan pengungkapan mengenai informasi keuangan di pemerintah daerah Queensland lebih lengkap jika dibandingkan dengan pengungkapan informasi non-keuangan (Ryan, Stanley, \& Nelson 2002).

Penelitian ini berusaha mengetahui faktor-faktor yang mempengaruhi tingkat pengungkapan dalam laporan keuangan yang disajikan oleh pemerintah daerah kabupaten/kota di Jawa Tengah dengan mengadopsi model pengukuran Local Government Indeks (LGA) Index dari penelitian sebelumnya milik Ryan, Stanley, dan Nelson (2002) dan disesuaikan dengan standar akuntansi pemerintah yang berlaku di Indonesia. Adapun perbedaan dengan penelitian sebelumnya adalah sebagai variabel independen, penelitian ini menggunakan variabel tingkat ketergantungan dengan proksi Dana Bagi Hasil, Dana Alokasi Umum, Dana Alokasi Khusus, yang merupakan komponen dana perimbangan pemerintah daerah. Selain itu, penelitian ini menambahkan kompleksitas pemerintahan dengan proksi jumlah penduduk miskin sebagai variabel independen yang mempengaruhi tingkat pengungkapan yang dilakukan oleh pemerintah daerah.

Tingkat pengungkapan dalam laporan keuangan daerah merupakan salah satu unsur penting yang harus dijaga demi menjaga akuntabilitas keuangan pemerintah. Besarnya tingkat ketergantungan daerah dan kompleksitas pemerintahan diduga merupakan faktor pendorong bagi pemerintah daerah dalam menjaga reputasi melalui akuntabilitas laporan keuangannya. Penelitian ini bertujuan untuk menguji pengaruh tingkat ketergantungan daerah terhadap tingkat pengungkapan Laporan Keuangan Pemerintah Daerah dan menguji pengaruh kompleksitas pemerintahan terhadap tingkat pengungkapan Laporan Keuangan Pemerintah Daerah.

\section{KAJIAN PUSTAKA DAN PERUMUSAN HIPOTESIS}

\section{Pengungkapan dalam Laporan Keuangan}

Kata pengungkapan memiliki arti tidak menutupi atau tidak menyembunyikan (Ghozali \& Chariri 2011). Hal tersebut mengandung pengertian bahwa pengungkapan informasi tersebut harus mampu menjelaskan dan dapat mewakili keadaan yang sebenarnya dari suatu entitas. Apabila dikaitkan dengan laporan keuangan, pengungkapan mengandung arti bahwa laporan keuangan harus memberikan informasi dan penjelasan yang cukup mengenai aktivitas suatu unit usaha

Landasan diperlukannya praktik pengungkapan laporan keuangan oleh manajemen untuk para pihak terkait didasarkan pada adanya teori keagenan (agency theory). Teori keagenan menyangkut hubungan kontraktual di antara dua pihak, yaitu principal dan agent. Principal menyediakan fasilitas dan dana untuk menjalankan perusahaan, di lain pihak manajemen sebagai agen mempunyai kewajiban untuk mengelola apa yang diamanahkan pemegang saham kepadanya. Agen diwajibkan 
memberikan laporan periodik pada principal tentang usaha yang dijalankannya. Prinsipal akan menilai kinerja agennya melalui laporan keuangan yang disampaikan, sehingga laporan keuangan tersebut merupakan sarana akuntabilitas manajemen kepada pemiliknya.

Masalah yang berkaitan dengan seberapa banyak informasi perlu diungkapkan dalam laporan keuangan sangat dipengaruhi oleh tujuan pelaporan keuangan. Seperti disebutkan dalam Statement of Financial Accounting Concept (SFAC) No.1, bahwa tujuan pelaporan keuangan (financial reporting) adalah lebih luas dibandingkan laporan keuangan (financial statement). Dengan kata lain, cakupan pelaporan keuangan adalah lebih luas dibandingkan laporan keuangan. FASB menyebutkan bahwa pelaporan keuangan mencakup tidak hanya laporan keuangan, tetapi juga media pelaporan informasi lainnya, yang berkaitan langsung atau tidak langsung dengan informasi yang disediakan oleh sistem akuntansi, yaitu informasi tentang sumber-sumber ekonomi, hutang, laba periodik, dan lain-lain.

\section{Stakeholder Theory}

Menurut Laan (2009) stakeholder theory dapat memberikan penjelasan tentang akuntabilitas kepada pemegang saham. Kelangsungan hidup perusahaan tergantung pada dukungan stakeholder. Dalam hal ini, perusahaan bukanlah entitas yang hanya beroperasi untuk kepentingannya sendiri, dan untuk mendapatkan dukungan dari stakeholder perusahaan harus memberikan manfaat bagi para stakeholdernya. Definisi stakeholder menurut Freeman dan McVea (2001) adalah setiap kelompok atau individu dapat mempengaruhi atau dipengaruhi oleh pencapaian tujuan organisasi. Teori stakeholder adalah teori yang menggambarkan kepada pihak mana saja atau stakeholder mana perusahaan bertanggungjawab Freeman dan McVea (2001). Perusahaan swasta maupun publik harus bersedia menyiapkan laporan keuangan dan mengungkapkan informasi penting yang terkait dengan organisasi kepada pemangku kepentingannya atau stakeholder (Mahmudi 2006). Terkait dengan tugas untuk menegakkan akuntabilitas keuangan publik, pemerintah bertanggung jawab untuk mempublikasikan laporan keuangan kepada pemangku kepentingan atau stakeholder. Hal ini dikarenakan, informasi yang disajikan dalam laporan keuangan akan digunakan oleh stakeholder untuk menilai pengukuran kinerja keuangan sebagai dasar dalam pengambilan keputusan.

\section{Teori Institusional}

Teori institusional organisasi memberikan pandangan yang kaya dan kompleks tentang organisasi. Inti utama dari teori institusional adalah terbentuknya organisasi oleh karena tekanan lingkungan institusional yang menyebabkan terjadinya institusionalisasi. Menurut Zucker (1987) dalam teori ini, organisasi dipengaruhi oleh tekanan normatif, yang timbul baik dari sumber eksternal seperti negara, ataupun yang timbul dari dalam organisasi itu sendiri. Tujuan utama dari perubahan organisasi adalah legitimasi formal Ashworth (2005). Dengan kata lain, 
organisasi menyesuaikan karakteristik internal mereka agar sesuai dengan harapan para pemangku kepentingan utama di lingkungan mereka.

DiMaggio dan Powell (1983) mengidentikasi tiga proses bagaimana sebuah organisasi menyesuaikan diri. Pertama, coercive isomorphism yaitu proses penyesuaian menuju kesamaan dengan cara "pemaksaan". Tekanan datang dari pengaruh politik dan masalah legitimasi. Misalnya, tekanan resmi datang dari peraturan pemerintah agar bisa diakui. Dalam hal ini, DiMaggio dan Powell (1983) memberikan contoh organisasi pengembangan masyarakat, ketika berhadapan dengan lembaga donor yang lebih berkuasa, merasa berada dalam tekanan harus menjadi lebih birokratis karena harus memenuhi tuntutan donor agar lebih tertib dalam mengelola uang.

Kedua, mimetic isomorphism yaitu proses dimana organisasi meniru organisasi lain yang berhasil dalam satu bidang, meskipun organisasi peniru tidak tahu persis mengapa mereka meniru, bukan karena dorongan supaya lebih efisien. Meskipun proses peniruan bagi organisasi pemasaran atau bisnis lebih banyak didorong keinginan menjadi efisien dibandingkan dengan organisasi nir-laba, seperti sekolah, rumah sakit, dan lembaga pemerintahan lainnya. Biasanya proses peniruan ini muncul di lingkungan yang tidak pasti. Contohnya adalah manajemen perusahaan Jepang yang banyak ditiru oleh perusahaan dari negara lain karena dianggap berhasil.

Ketiga, normative isomorphism sering diasosiasikan dengan profesionalisasi dan menangkap tekanan normatif yang muncul di bidang tertentu. Norma atau sesuatu yang tepat bagi organiasi berasal dari pendidikan formal dan sosialisasi pengetahuan formal itu di bidang tertentu yang menyokong dan menyebarkan kepercayaan normatif itu. Ketika profesionalisme meningkat maka tekanan normatif juga akan meningkat. Oleh karena itu, Dalam tema bahasan pemerintahan, untuk menyesuaikan diri dengan keinginan dari para pemangku kepentingan dan menjaga kepercayaan yang telah diberikan, pemerintah perlu memberikan sebuah informasi lengkap mengenai pertanggungjawaban pengelolaan keuangan mereka.

\section{Tingkat Ketergantungan Daerah}

Robbins dan Austin (1986) memaparkan bahwa intergovernmental revenue merepresentasikan tingkat ketergantungan pemerintah daerah. Tingkat ketergantungan yang tinggi cenderung meningkatkan tingkat pengungkapan. Hal ini disebabkan adanya kepentingan bagi pemerintah pusat untuk memantau apa yang dilakukan pemerintah daerah dan tingkat pencapaian kinerja atas alokasi dana yang telah diberikan oleh Pemerintah Pusat.

Tingkat ketergantungan terhadap dana transfer dari pemerintah pusat di Indonesia tercermin dari besarnya dana perimbangan yang diberikan. Definisi dana perimbangan menurut Undang- Undang Nomor 33 tahun 2004 adalah dana yang bersumber dari Anggaran Pendapatan dan Belanja Negara yang dialokasikan kepada daerah untuk mendanai kebutuhan daerah dalam rangka pelaksanaan desentralisasi. 
Dana perimbangan terdiri atas: (1) Dana Alokasi Umum; (2) Dana Alokasi Khusus; dan (3) Dana Bagi Hasil.

\section{Kompleksitas Pemerintahan}

Mengutip dari Pasal 28 ayat 2 UU No. 33 Tahun 2004, besarnya penduduk mencerminkan besarnya kebutuhan akan penyediaan layanan publik di setiap daerah. Semakin banyak jumlah penduduk, semakin besar tuntutan akan pengungkapan yang dilakukan oleh pemerintahnya mengingat fungsi pemerintah sebagai abdi masyarakat. Ingram (1984) memaparkan bahwa variabel kompleksitas pemerintahan (yang diproksi dengan jumlah penduduk) memberikan dorongan kepada pemerintah daerah untuk meningkatkan pengungkapan pada laporan keuangannya. Penduduk miskin juga merupakan anggota dari populasi penduduk di Indonesia. Penekanan tanggung jawab pemerintah atas penduduk miskin di Indonesia tersurat dalam batang tubuh Undang-Undang Dasar 1945 Pasal 34 ayat 1.

\section{Pengaruh Tingkat Ketergantungan Daerah terhadap Tingkat Pengungkapan}

Ide utama Stakeholder Theory adalah bahwa kesuksesan organisasi bergantung pada bagaimana cara organisasi tersebut membina hubungan dengan para kelompok kunci, seperti pelanggan, karyawan, pemasok, dan pihak lain yang dapat mempengaruhi pencapaian tujuan perusahaan (Freeman \& McVea 2001). Perusahaan harus menjaga hubungan dengan stakeholdernya dengan mengakomodasi keinginan dan kebutuhan stakeholdernya, terutama stakeholder yang mempunyai power terhadap ketersediaan sumber daya yang digunakan untuk aktivitas operasional perusahaan, misal tenaga kerja, pasar atas produk perusahaan dan lain-lain (Ghozali \& Chariri 2011).

Di dalam pemerintahan, pemerintah pusat memiliki kepentingan untuk memantau program-program yang telah dilaksanakan pemerintah daerah dalam menggunakan Anggaran Pendapatan dan Belanja Daerah (APBD) dan pencapaian kinerja atas dana alokasi yang diberikan pemerintah pusat. Robbins dan Austin (1986) menemukan bahwa tingkat ketergantungan daerah berpengaruh positif terhadap tingkat pengungkapan laporan keuangan pemerintah kota. Hal ini mengindikasikan bahwa, semakin besar Dana Alokasi Umum yang diberikan oleh pemerintah pusat, menunjukkan semakin besar pula tingkat ketergantungan pemerintah daerah terhadap sumber dana lain dalam mendanai belanjanya. Kaitannya dengan stakeholder theory, pemerintah daerah harus melakukan pengungkapan informasi yang memadai agar kepentingan para stakeholder terpenuhi.

H1a: Tingkat ketergantungan akan Dana Alokasi Umum berpengaruh terhadap tingkat pengungkapan dalam Laporan Keuangan Pemerintah Daerah. 
H1b: Tingkat ketergantungan akan Dana Alokasi Khusus berpengaruh terhadap tingkat pengungkapan dalam laporan keuangan pemerintah Daerah.

H1c: Tingkat ketergantungan akan Dana Bagi Hasil berpengaruh terhadap tingkat pengungkapan dalam laporan keuangan pemerintah daerah.

\section{Pengaruh Kompleksitas Pemerintahan terhadap Tingkat Pengungkapan}

Dalam Teori institusional menurut Zucker (1987), organisasi dipengaruhi oleh tekanan normatif, yang timbul baik dari sumber eksternal, ataupun yang timbul dari dalam organisasi itu sendiri. Dalam lingkup pemerintahan, organisasi pemerintahan dituntut untuk mewujudkan pengelolaan yang baik oleh para pemangku kepentingan utama di lingkungan mereka termasuk masyarakat. Selain itu, dukungan mengenai hal ini juga diusung dalam salah satu perspektif baru pemerintahan dalam New Public Management menurut Osborne dan Gaebler dalam Mardiasmo (2002) pemerintah kini berorientasi pada pelanggan yaitu pemerintah diharapkan dapat memenuhi kebutuhan pelanggan, bukan birokrasi.

Besarnya jumlah penduduk mencerminkan besarnya kebutuhan akan penyediaan layanan publik di setiap daerah. Semakin banyak jumlah penduduk, semakin besar tuntutan akan pengungkapan yang dilakukan oleh pemerintahnya mengingat fungsi Pemerintah sebagai abdi masyarakat. Ingram (1984) memaparkan bahwa variabel kompleksitas pemerintahan memberikan dorongan kepada pemerintah daerah untuk meningkatkan pengungkapan pada laporan keuangannya.

Penelitian ini berusaha memberikan kontribusi dengan menggunakan proksi jumlah penduduk miskin dalam mengukur kompleksitas pemerintahan. Hal ini didasarkan pada pemikiran bahwa pemerintah lebih bertanggung jawab terhadap penduduk miskin, sebagaimana tertuang dalam batang tubuh Undang-Undang Dasar 1945 pasal 34 ayat 1 yang menekankan tanggungjawab pemerintah terhadap rakyat miskin. Berdasarkan uraian tersebut, hipotesis yang diajukan adalah sebagai berikut:

H2: Kompleksitas pemerintahan berpengaruh terhadap tingkat pengungkapan dalam laporan keuangan pemerintah daerah.

\section{METODA PENELITIAN}

\section{Sampel dan Data Penelitian}

Jenis data yang dipakai dalam penelitian ini adalah data sekunder. Data sekunder dalam penelitian ini diperoleh dari Badan Pemeriksa Keuangan Republik Indonesia berupa laporan keuangan pemerintah daerah kabupaten/kota yang berada di Jawa Tengah. Penentuan sampel dalam penelitian ini menggunakan metode Purposive Sampling, dari keseluruhan populasi yang ada dipilih kembali berdasarkan kriteria tertentu yaitu merupakan pemerintah daerah kabupaten/kota yang berada di 
propinsi Jawa Tengah. Pemerintah daerah tersebut telah memublikasikan laporan keuangan periode tahun 2009 sampai dengan tahun 2011 secara lengkap dan telah diaudit oleh Badan Pemeriksa Keuangan. Alasan digunakannya periode pengamatan tersebut adalah karena pada periode tersebut, tingkat pemerolehan opini wajar tanpa pengecualian sangatlah rendah, sehingga menarik untuk diuji faktor apa saja yang mempengaruhi hal tersebut.

Pada tabel 1 diketahui Provinsi Jawa Tengah memiliki 35 pemerintah kabupaten/kota yang terdiri dari 29 kabupaten dan 6 kota. Dari jumlah tersebut, hanya kota Salatiga yang laporan keuangannya tidak dapat diakses secara lengkap melalui Badan Pemeriksa Keuangan pada tahun 2010. Sedangkan, pemerintah daerah yang memiliki data outlier adalah pemerintah kabupaten Banyumas dan Pemerintah Kota Semarang. Hal ini mungkin disebabkan karena data yang dimiliki oleh pemerintah kabupaten total skor LGA yang diperoleh kedua pemerintah daerah tersebut jauh lebih besar di antara skor LGA yang diperoleh daerah lain, yaitu lebih dari 75 persen. Hal ini mengindikasikan bahwa kedua daerah tersebut telah mengungkapkan informasi yang lebih banyak dibandingkan dengan daerah lainnya.

Tabel 1

Prosedur Pemilihan Sampel

\begin{tabular}{lc}
\hline \multicolumn{1}{c}{ Keterangan } & Jumlah \\
\hline Jumlah Kabupaten atau Kota yang terletak di Provinsi Jawa Tengah pada tahun & 35 \\
2009-2011 & \\
(-) Kabupaten atau Kota yang laporan keuangan tahunannya tidak dapat diakses \\
secara lengkap periode tahun 2009-2011 \\
$\begin{array}{l}\text { (-) Data } \text { outlier } \\
\text { Jumlah sampel yang digunakan }\end{array}$ \\
\hline
\end{tabular}

\section{Definisi Operasional Variabel dan Pengukuran Variabel}

\section{Variabel Dependen}

Variabel dependen dalam penelitian ini adalah tingkat pengungkapan dalam laporan keuangan. Penelitian ini mengembangkan indeks pengungkapan dalam penelitian sebelumnya milik Ryan, Stanley, dan Nelson (2002) yaitu Local Government Accountability (LGA) Index. Local Government Accountability (LGA) index merupakan ukuran yang digunakan untuk mengetahui sejauh mana tingkat kualitas pengungkapan dalam rangka penilaian akuntabilitas pemerintah daerah (Ryan, Stanley, \& Nelson 2002). Ryan, Stanley, dan Nelson (2002) menjelaskan bahwa pada awalnya, kriteria dan pengukuran indeks tersebut dikembangkan oleh Dixon dengan nama Modified Accountability Disclosure Index (MAD) Index berdasarkan analisis literatur pemerintahan, peraturan pemerintah, standar akuntansi, rekomendasi serta konsultasi praktisi seperti Municipal Association of Victoria and the Public Estimates and Account Committee. Selain itu, indeks pengungkapan tersebut juga telah divalidasi secara eksternal sebagai referensi praktisi dan peneliti 
di berbagai negara. Kemudian di tahun 2002, Ryan, Stanley, dan Nelson (2002) menyesuaikan indeks tersebut untuk mengukur tingkat pengungkapan di lingkungan pemerintah daerah dan menyebut modifikasian indeks tersebut dengan Local Government Accountability (LGA) Index. Penelitian ini berusaha memodifikasi indeks yang telah dibuat oleh peneliti sebelumnya, yaitu Ryan, Stanley, dan Nelson (2002).

Oleh karena sebelumnya LGA index digunakan di Australia, hasil modifikasian dari LGA Index (Modified LGA Indeks) telah disesuaikan dengan Standar Akuntansi Pemerintahan yang berlaku di Indonesia. Hal ini dilakukan dengan memilih kriteria-kriteria ada dalam indeks yang sesuai dengan Standar Akuntansi Pemerintahan di Indonesia. Selain itu, peneliti juga berusaha menggolongkan indeks tersebut menjadi kelompok indeks untuk pengungkapan wajib (mandatory reports) dan indeks untuk pengungkapan sukarela (voluntary reports). Dari total 22 kriteria LGA index yang ada, penelitian ini hanya menggunakan 15 kriteria dan menambah 2 kriteria tambahan pada kelompok laporan keuangan sukarela.

Variabel Independen dalam penelitian ini adalah tingkat ketergantungan daerah penelitian ini juga berusaha menguji pengaruh tingkat ketergantungan keuangan pemerintah daerah dengan lebih spesifik menggunakan tingkat ketergantungan daerah terhadap Dana Alokasi Umum (DAU), Dana Alokasi Khusus (DAK), serta Dana Alokasi Bagi Hasil (DBH), dengan rumus sebagai berikut:

$\mathrm{DAU}=\mathrm{DAU} /$ Total realisasi anggaran pendapatan

DAK $=\mathrm{DAK} /$ Total realisasi anggaran pendapatan

$\mathrm{DBH}=\mathrm{DBH} /$ Total realisasi anggaran pendapatan

Variabel kompleksitas pemerintahan diukur denganjumlah penduduk miskin (PM) sebagai proksi dari kompleksitas pemerintah, dengan rumus yang digunakan adalah:

$\mathrm{PM} \quad=$ Log (Jumlah Penduduk Miskin)

Variabel kontrol adalah Ukuran Pemerintah Daerah (size) yang banyak digunakan untuk menjelaskan pengungkapan informasi perusahaan adalah ukuran perusahaan. Sejalan dengan pernyataan tersebut, penelitian ini berusaha menguji pengaruh ukuran pemerintah terhadap tingkat pengkungkapan dalam laporan keuangan pemerintah daerah. Ukuran pemerintah daerah diproksikan dengan hasil logaritma dari total aset. Sehingga, jika dituliskan ke dalam rumus adalah sebagai berikut:

AS $\quad=\log ($ Total Aset Pemda $)$ 


\section{Model Persamaan Regresi}

Model regresi linier digunakan digunakan untuk mengetahui pengaruh antar variabel terikat dan variabel bebas. Pengujian masing-masing hipotesis dilakukan dengan menguji masing-masing koefisien regresi dengan uji t. model regresi linier berganda ditunjukkan oleh persamaan berikut ini:

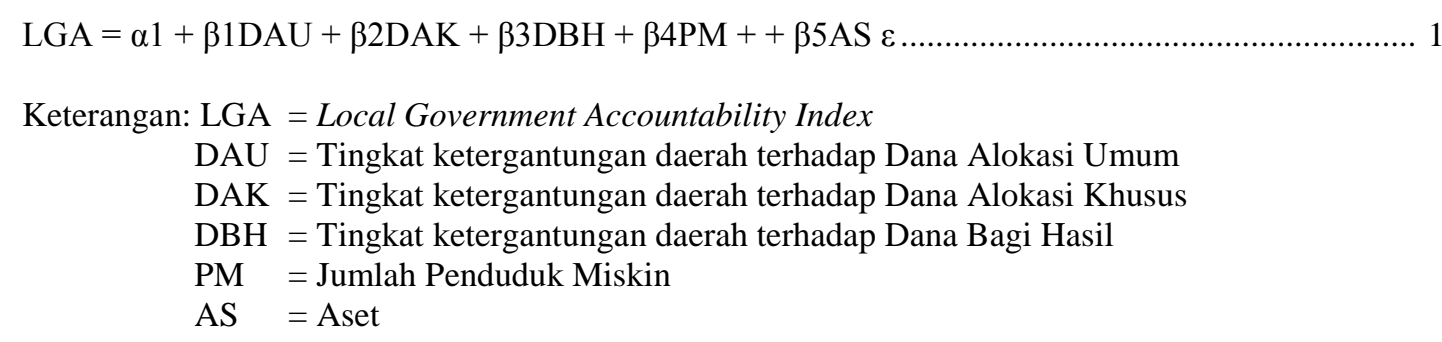

\section{ANALISIS DAN PEMBAHASAN}

Pengujian statistik deskriptif untuk jumlah sampel dalam penelitian ini adalah sebanyak 96 observasi selama tahun 2009-2011. Pengujian ini meliputi pengujian terhadap nilai minimum, maksimum, dan rata-rata. Berdasarkan output dari statistik deskriptif, diketahui sampel yang digunakan sebanyak 96 laporan keuangan pemerintah kabupaten/kota. Tingkat pengungkapan yang paling rendah sebesar 37,60 persen, tingkat pengungkapan yang paling tinggi yaitu sebesar 71,80 persen. Jika dilihat dari rata-rata tingkat LGA yang diperoleh yaitu sebesar 58,46 persen, dapat disimpulkan bahwa pemerintah daerah kabupaten/kota yang berada di provinsi Jawa Tengah telah melakukan pengungkapan yang cukup di dalam Laporan Keuangan mereka.

Jika ditinjau berdasarkan nilai DAU, nilai DAU minimum sebesar 0,460 atau 46,00 persen, sedangkan nilai DAU yang maksimum sebesar 0,741 atau 74,10 persen. Rata-rata nilai DAU pada sampel penelitian ini sebesar 0,61660 atau sebesar 61,66 persen. Dari data rasio ketergantungan akan DAU tersebut maka dapat disimpulkan bahwa secara rata-rata,pemerintah daerah dalam penelitian ini masih memiliki tingkat ketergantungan yang tinggi terhadap pemerintah pusat, karena lebih dari 50 persen total realisasi pendapatan daerah bersumber dari Dana Alokasi Umum.

Nilai Dana Alokasi Khusus (DAK) minimum pada tabel 2 diketahui sebesar 0,032 atau 3,20 persen, sedangkan DAK maksimum diperoleh dengan nilai sebesar 0,155 atau 15,50 persen. Rata-rata nilai DAK pada sampel penelitian ini sebesar 6,19 persen. Ditinjau dari nilai DBH, terlihat bahwa nilai minimum DBH sebesar 0,034 atau 3,40 persen, sedangkan nilai DBH pemerintah daerah yang maksimum diperoleh sebesar 0,155 atau 15,50 persen. Rata-rata nilai $\mathrm{DBH}$ pada sampel penelitian ini sebesar 5,74 persen.

Ditinjau dari Kompleksitas Pemerintahan (KP) yang diukur berdasarkan jumlah penduduk miskin (PM), pada tabel 2 ditunjukkan nilai minimum sebesar 
4,093 atau sebesar 12.400 jiwa penduduk. Sedangkan nilai PM maksimum sebesar 5,636 atau setara dengan 432.398 penduduk. Adapun rata-rata jumlah penduduk miskin di wilayah kabupaten/kota di Jawa Tengah adalah sebesar 5,10714.

Size pemerintah daerah diukur berdasarkan total aset pemerintah daerah dan luas wilayah daerah tersebut. Adapun nilai minimum dari size sebesar 11,97, sedangkan nilai maksimum diperoleh sebesar 13,12. Rata-rata nilai total aset (size) pada sampel penelitian ini adalah sebesar 12,32 (Log dari total aset) atau setara dengan $\mathrm{Rp} 2.370 .574 .907 .089,56$.

Tabel 2

Statistik Deskriptif

\begin{tabular}{llccc}
\hline Variabe & $\mathbf{N}$ & Minimum & Maximum & Rata-rata \\
\hline LGA & 96 & 0,376 & 0,718 & 0,584 \\
DAU & 96 & 0,460 & 0,741 & 0,616 \\
DAK & 96 & 0,032 & 0,155 & 0,069 \\
DBH & 96 & 0,034 & 0,155 & 0,063 \\
PM & 96 & 4,093 & 5,636 & 5,107 \\
AS & 96 & 11,966 & 13,117 & 12,315 \\
\hline
\end{tabular}

\section{Uji Asumsi Klasik}

Berdasarkan uji normalitas residual yang telah dilakukan, diperoleh nilai Asymp. Sig. (2-tailed) lebih besar dari 0,05 yaitu sebesar 0,145 (0,145>0,05). Maka dapat disimpulkan bahwa model memiliki nilai residual terstandarisasi yang berdistribusi normal. Dalam penelitian ini, peneliti melakukan uji heterokedastisitas dengan menggunakan metode Park yaitu dengan meregresikan semua variabel bebas terhadap nilai Ln Residual kuadrat. Gejala heterokedastisitas ditunjukkan oleh koefisien regresi dari ln masing-masing variabel bebas terhadap ln residual kuadrat $\left(\mathrm{LnU}^{2}\right)$, dengan kriteria nilai probabilitas lebih besar dari nilai alpha (Sig. $>\alpha$ ) atau $\mathrm{t}_{\text {hitung }}<\mathrm{t}_{\text {tabel }}$ (Suliyanto 2011).

Berdasarkan hasil uji Park diketahui bahwa tingkat signifikansi dari masingmasing variabel adalah di atas 0,05 . Hal ini menunjukkan bahwa tidak ada satupun variabel yang signifikan mempengaruhi nilai absolutnya, sehingga dapat disimpulkan bahwa model regresi tidak terjadi gejala heteroskedastisitas. Hasil uji heteroskedastisitas dapat dilihat pada tabel 3.

Dalam menguji adanya otokorelasi atau tidak, peneliti menggunakan uji Lagrange Multiplier (LM test). Diketahui nilai $\mathrm{R}^{2}$ hasil uji LM di atas adalah sebesar 0,202, dan jumlah pengamatan sebanyak 96, maka $X^{2}$ hitung $=96 \times 0,202=19,392$. Sedangkan, nilai $X^{2}$ tabel dengan df $(95 ; 0,05)$ sebesar 118,752. Hasil tersebut menunjukkan bahwa $X^{2}$ hitung $(19,392) \leq X^{2}$ tabel $(118,752)$, sehingga dapat disimpulkan bahwa tidak terjadi masalah otokorelasi. 
Tabel 3

Uji Heteroskedastisitas

\begin{tabular}{|c|c|c|c|}
\hline Variabel & $\mathbf{T}$ & Sig. & Keterangan \\
\hline LNDAU & 0,461 & 0,646 & Tidak terdapat heteroskedastisitas \\
\hline LNDAK & $-0,142$ & 0,887 & Tidak terdapat heteroskedastisitas \\
\hline LNDBH & 1,784 & 0,078 & Tidak terdapat heteroskedastisitas \\
\hline LNPM & 1,637 & 0,105 & Tidak terdapat heteroskedastisitas \\
\hline LNAS & $-0,138$ & 0,891 & Tidak terdapat heteroskedastisitas \\
\hline
\end{tabular}

Uji multikolinieritas dapat dilihat dari tolerance value dan VIF (Varians Inflation Factor). Berdasarkan hasil uji multikolinieritas yang dilakukan dalam penelitian ini, diketahui bahwa tolerance value untuk semua variabel lebih besar dari 0,10 sedangkan nilai Varians Inflation Factor (VIF) lebih kecil dari 10. Jadi dapat disimpulkan bahwa model regresi yang terbentuk tidak terjadi gejala multikolinieritas. Hasil uji multikolinieritas disajikan dalam tabel 4.

Tabel 4

Hasil Uji Multikolinearitas

\begin{tabular}{lccl}
\hline \multirow{2}{*}{ Variabel } & \multicolumn{2}{c}{ Statistik Kolinieritas } & \\
\cline { 2 - 3 } & Tolerance & VIF & Keterangan \\
\hline DAU & 0,815 & 1,227 & Tidak terdapat multikolinearitas \\
DAK & 0,863 & 1,159 & Tidak terdapat multikolinearitas \\
DBH & 0,849 & 1,178 & Tidak terdapat multikolinearitas \\
PM & 0,887 & 1,128 & Tidak terdapat multikolinearitas \\
AS & 0,915 & 1,093 & Tidak terdapat multikolinearitas \\
\hline
\end{tabular}

\section{Uji Hipotesis}

Koefisien Determinasi $\left(\mathrm{R}^{2}\right)$ pada intinya mengukur seberapa jauh kemampuan model dalam menerangkan variasi variabel dependen (Suliyanto 2011). Nilai koefisien determinasi $\left(\mathrm{R}^{2}\right)$ berada diantara nilai 0 dan 1 . Nilai $\left(\mathrm{R}^{2}\right)$ yang kecil memiliki arti bahwa kemampuan variabel-variabel independen dalam menjelaskan variasi variabel dependen amat terbatas. Nilai $\left(\mathrm{R}^{2}\right)$ yang mendekati satu berarti variabel-variabel independen memberikan hampir semua informasi yang dibutuhkan dalam memprediksi variasi variabel dependen. Pada tabel 5 disajikan hasil uji regresi, di mana nilai $\mathrm{R}^{2}$ diperoleh sebesar 0,104 yang berarti bahwa 10,4 persen variasi tingkat pengungkapan dapat dijelaskan oleh kelima variabel sedangkan sisanya 89,6 persen dijelaskan oleh variabel lain yang tidak diuji dalam model ini.

Uji kelayakan model digunakan untuk menguji apakah semua variabel independen berpengaruh terhadap variabel dependennya. Pada tabel 5, diketahui bahwa nilai $F$ hitung pada ANOVA sebesar 3,206 sedangkan $F$ tabel sebesar 2,305. Dengan demikian F hitung lebih besar dari F tabel, serta nilai signifikansi F hitung 
$(0,01)$ lebih kecil dari 0,05 . Jadi dapat disimpulkan bahwa model yang digunakan layak (fit).

Berdasarkan hasil uji regresi berganda yang dilakukan, jika dilihat dari tingkat signifikasinya, diketahui dari tabel 5 bahwa seluruh variabel yang diteliti hanya dua variabel independen yang berpengaruh secara signifikan terhadap variabel dependennya yaitu pada variabel tingkat ketergantungan terhadap Dana Alokasi Umum $(0,013)$ dan tingkat ketergantungan terhadap Dana Bagi Hasil $(0,029)$. Hal tersebut dapat terlihat dari tingkat signifikansi kedua variabel tersebut lebih kecil dari 0,05. Sedangkan variabel-variabel independen lainnya yaitu DAK, dan PM memiliki tingkat signifikansi di atas 0,05 . Berikut ini merupakan ringkasan hasil uji regresi berganda.

Tabel 5

Ringkasan Hasil Uji Regresi Berganda

\begin{tabular}{lcc}
\hline \multicolumn{1}{c}{ Variabel } & t & Sig. \\
\hline (Konstanta) & 2,031 & 0,045 \\
DAU & 2,532 & 0,013 \\
DAK & $-1,106$ & 0,272 \\
DBH & $-2,214$ & 0,029 \\
PM & $-1,185$ & 0,239 \\
AS & $-0,777$ & 0,439 \\
Koefisien determinasi R ${ }^{2}$ & & 0,104 \\
Sig. F & & 0,010 \\
F hitung & & 3,206 \\
F table & & 2,305 \\
*Signifikansi $\alpha=0,05$ & & \\
\hline
\end{tabular}

\section{ANALISIS DAN PEMBAHASAN}

\section{Pengaruh Tingkat Ketergantungan Daerah terhadap Tingkat Pengungkapan}

Berdasarkan hasil regresi, diketahui bahwa variabel tingkat ketergantungan daerah terhadap DAU berpengaruh terhadap tingkat pengungkapan laporan keuangan pemerintah daerah di Jawa Tengah. Penelitian ini konsisten dengan penelitian (Robbins \& Austin 1986). Robbins dan Austin (1986) berhasil membuktikan bahwa pada model regresi, bentuk ketergantungan pemerintahan terhadap hutang dan ketergantungan dana federal adalah variabel yang berpengaruh signifikan terhadap kualitas pengungkapan.

Dari hasil pengolahan secara statistik, diketahui bahwa arah hubungan antara dua variabel tersebut adalah positif. Hasil penelitian ini juga sejalan dengan (Puspita \& Martini (2012) yang menunjukkan bahwa rasio ketergantungan berpengaruh positif terhadap pengungkapan konten website pemda. Hal ini mengindikasikan bahwa semakin tinggi Dana Alokasi Umum yang ditransfer oleh pemerintah pusat, 
maka akan semakin tinggi pula tingkat informasi yang diungkapkan dalam laporan keuangan pemerintah daerah.

Sesuai stakeholder theory yang mengemukakan bahwa kesuksesan organisasi bergantung pada bagaimana cara organisasi tersebut membina hubungan dengan para kelompok kunci, seperti pelanggan, karyawan, pemasok, financiers, dan pihak lain yang dapat mempengaruhi pencapaian tujuan perusahaan (Freeman \& McVea 2001). Oleh pemerintah daerah pengungkapan dalam laporan keuangan pemerintah daerah yang cukup dianggap sebagai salah satu bentuk pertanggungjawaban dalam hal penggunaan Dana Alokasi Umum kepada pemerintah pusatdan juga pemenuh harapan stakeholder dalam pengambilan keputusan.

Variabel tingkat ketergantungan daerah terhadap DAK tidak berpengaruh terhadap tingkat pengungkapan laporan keuangan pemerintah daerah di Jawa Tengah. Tidak berpengaruhnya tingkat ketergantungan daerah terhadap Dana Alokasi Khusus terhadap tingkat pengungkapan dalam laporan keuangan daerah mungkin saja disebabkan karena tujuan Dana Alokasi Khusus yang bersifat khusus hanya untuk daerah tertentu dengan kemampuan fiskal rendah justru tidak tercapai di Indonesia. Dengan kata lain, daerah dengan kemampuan fiskal yang tinggi yang seharusnya mampu membiayai prioritas nasional juga tetap mendapatkan Dana Alokasi Khusus. Oleh karena itu, penggunaan rasio ketergantungan daerah terhadap Dana Alokasi Khusus menjadi kuranglah tepat karena tidak mencerminkan tingkat ketergantungan daerah yang sebenarnya. Selain itu, kemungkinan hal ini juga disebabkan adanya PP No. 55 Tahun 2005 Pasal 63 mengenai Pelaporan, dimana mengatur tentang kewajiban penyampaian laporan pertanggungjawaban atas penggunaan dan pelaksanaan Dana Alokasi Khusus bagi tiap daerah secara triwulanan. Oleh karena laporan pertanggungjawaban atas Dana Alokasi Khusus telah disampaikan secara triwulanan, secara otomatis besarnya transfer DAK oleh pemerintah pusat tidaklah mempengaruhi informasi yang diungkapkan dalam laporan keuangan daerah tidaklah berpengaruh.

Variabel tingkat ketergantungan daerah terhadap DBH berpengaruh terhadap tingkat pengungkapan laporan keuangan pemerintah daerah di Jawa Tengah. Arah hubungan negatif dalam pengaruh tingkat ketergantungan terhadap Dana Bagi Hasil terhadap tingkat pengungkapan dalam laporan keuangan pemerintah daerah diduga adalah karena fenomena permasalahan moral hazard yang dilakukan oleh pemerintah daerah terhadap Dana Bagi Hasil (DBH) yang marak terjadi di Indonesia akhir-akhir ini. Diduga pemerintah daerah cenderung menyediakan informasi asimetris kepada pemerintah pusat mengenai pengelolaan dana bagi hasil dengan mempersempit cakupan informasi yang diungkapkan dalam laporan keuangan pemerintah daerah mereka. Pada akhirnya, semakin tinggi DBH yang dikucurkan oleh pemerintah pusat membuat tingkat pengungkapan yang dilakukan pemerintah daerah semakin rendah. 


\section{Pengaruh Kompleksitas Pemerintahan terhadap Tingkat Pengungkapan}

Variabel jumlah penduduk miskin tidak berpengaruh terhadap tingkat pengungkapan laporan keuangan pemerintah daerah. Pengguna laporan keuangan pemerintah daerah memiliki kebutuhan akan informasi dalam laporan keuangan pemerintah guna menilai pertanggungjawaban kinerja suatu pemerintah daerah. Berkaitan dengan hal tersebut, kesadaran, wawasan, dan tingkat pendidikan penduduk miskin mungkin dapat menjadi alasan kurangnya minat mereka untuk membaca laporan keuangan pemerintah daerah. Hasil penelitian ini sejalan dengan temuan Robbins dan Austin (1986) yang membuktikan bahwa kompleksitas pemerintahan yang diproksikan dengan populasi penduduk tidaklah berpengaruh terhadap tingkat pengungkapan.laporan keuangan pemerintah. Selain itu, penelitian di dunia usaha juga menunjukkan hasil yang sama. Hossain (2008) membuktikan bahwa kompleksitas usaha tidak berpengaruh terhadap tingkat pengungkapan perusahaan.

\section{Variabel Kontrol}

Variabel total aset daerah tidak berpengaruh terhadap tingkat pengungkapan dalam laporan keuangan pemerintah daerah di Jawa Tengah. Hasil penelitian ini tidak sejalan dengan penelitian Puspita dan Martini (2012) dan juga Bhayani (2012). hasil penelitian ini konsisten dengan hasil penelitian Laswad, Fisher, dan Oyelere (2005), Hilmi dan Martani (2012), Hartatianti (2013). Hilmi dan Martani (2012) menunjukkan bahwa asset tidak berpengaruh terhadap tingkat pengungkapan laporan keuangan pemerintah provinsi. Sama halnya dengan Hartatianti (2013) menunjukkan bahwa variabel total asset tidak memiliki pengaruh terahadap tingkat pengungkapan yang harus dilakukan pemerintah provinsi berdasarkan Peraturan Pemerintah No. 71 tahun 2010. Hasil dari penelitian ini mengindikasikan bahwa besaran kepemilikan asset oleh daerah tidak mempengaruhi tingkat pengungkapan dalam laporan keuangan pemerintah daerah. Oleh karena itu, dapat disimpulkan bahwa model dalam penelitian ini adalah model yang baik.

\section{SIMPULAN, IMPLIKASI DAN SARAN}

\section{Simpulan}

Dari hasil penelitian, kesimpulan yang dapat ditarik adalah tingkat ketergantungan daerah terhadap Dana Alokasi Umum dan dan tingkat ketergantungan terhadap Dana Bagi Hasil berpengaruh terhadap tingkat pengungkapan dalam laporan keuangan daerah di Jawa Tengah. Sedangkan, tingkat ketergantungan daerah terhadap Dana Alokasi Khusus tidak berpengaruh terhadap tingkat pengungkapan Laporan Keuangan Pemerintah Daerah. Selain itu, kompleksitas pemerintah yang diproksikan dengan jumlah penduduk miskin tidak 
berpengaruh terhadap tingkat pengungkapan dalam laporan keuangan daerah di Jawa Tengah.

\section{Implikasi}

Implikasi dari penelitian ini adalah pemerintah daerah yang memiliki tingkat ketergantungan yang tinggi terhadap Dana Alokasi Umum dan Dana Bagi Hasil seharusnya mengungkapkan informasi yang lebih besar yang dibutuhkan oleh para pemangku kepentingan. Hal ini bertujuan agar laporan keuangan dapat menjadi relevan dan berkualitas sebagai dasar pengambilan keputusan para pemberi dana tersebut dalam menyalurkan dana yang akan diberikan. Selain itu, tingginya tingkat pengungkapan yang dilakukan pemerintah daerah dapat meningkatkan kepercayaan terhadap pengelolaan sumber daya modal yang diberikan.

\section{Saran}

Penelitian selanjutnya dapat juga mengembangkan penelitian yang khusus menguji terhadap pengungkapan terhadap komponen tertentu dalam laporan keuangan, misalnya Dana Bantuan Sosial.

\section{DAFTAR PUSTAKA}

Ashworth, Rachel, George Boyne, dan Rick Delbridge. 2005. "Institutional pressures on public organizations: an empirical test of isomorphism." Paper for the Public Management Research Association Conference, Los Angeles 28 (9): 61-62.

Bhayani, S. 2012. "The relationship between comprehensiveness of corporate disclosure and firm characteristics in india." Asia-Pasific Finance and Accounting Review 1 (1): 52-56.

DiMaggio, P J, dan W W Powell. 1983. "The iron cage revisited: Institutional isomorphism and collective rationality in organizational fields." American Sociological Review 48 (1): 147-60. https://doi.org/10.2307/2095101.

Freeman, Edward, dan John McVea. 2001. "A stakeholder approach to strategic management. working paper no. 01-02." Darden Business School, 1-32. https://doi.org/10.2139/ssrn.263511.

Ghozali, Imam, dan Anis Chariri. 2011. Teori akuntansi. Semarang: Badan Penerbit Fakultas Ekonomi Universitas Diponegoro.

Haning, J. 2003. “Accountability for performance in local government in indonesia: sustainability balanced scorecard approach for better practices of corporate governance." Flinders Institute of Public Policy and Management University.

Hartatianti, Nur. 2013. "Analisis faktor-faktor yang mempengaruhi tingkat pengungkapan laporan keuangan pada provinsi di indonesia (berdasarkan 
peraturan pemerintah no. 71 tahun 2010 tentang standar akuntansi pemerintahan)." UPN Veteran Yogyakarta.

Hilmi, Amiruddin Zul, dan Dwi Martani. 2012. "Analisis faktor-faktor yang mempengaruhi tingkat pengungkapan laporan keuangan tingkat propinsi." In Simposium Nasional Akuntansi 15, Banjarmasin.

Hossain, Mohammed. 2008. "The extent of disclosure in annual reports of banking companies: the case of india." European Journal of Scientific Research 23 (4): 659-80.

Ingram, Robert W. 1984. "Economic Incentives and the Choice of State Government Accounting Practices." Journal of Accounting Research 22 (1): 126-44. https://doi.org/10.2307/2490704.

Laan, Sandra Van Der. 2009. "The role of theory in explaining motivation for corporate social disclosures: voluntary disclosures vs ' solicited ' disclosures." Australlasian Accounting Business and Finance Journal 3 (4): 15-29. https://doi.org/10.2307/41166339.

Laswad, Fawzi, Richard Fisher, dan Peter Oyelere. 2005. "Determinants of voluntary Internet financial reporting by local government authorities." Journal of Accounting and Public Policy 24: 101-21. https://doi.org/10.1016/j.jaccpubpol.2004.12.006.

Mahmudi. 2006. Analisis Laporan Keuangan Pemerintah Daerah. Yogyakarta: UPP STIM YKPN. Yogyakarta: UPP STIM YKPN.

Mardiasmo. 2002. "Elaborasi reformasi akuntansi sektor publik: telaah kritis terhadap upaya aktualisasi kebutuhan sistem akuntansi keuangan pemerintah daerah." Jurnal Akuntansi \& Auditing Indonesia 6 (1): 63-82.

Mulgan, Richard. 2002. "Accountability issues in the new model of governance. Discussion paper No.91." Australian National University Publishing.

Puspita, Rora, dan Dwi Martini. 2012. “Analisis pengaruh kinerja dan karakteristik pemda terhadap tingkat pengungkapan dan kualitas informasi dalam website pemda." In Simposium Nasional Akuntansi XV, 26. Banjarmasin.

Robbins, Walter A., dan Kenneth R. Austin. 1986. "Disclosure quality in governmental financial reports: an assessment of the appropriateness of a compound measure." Journal of Accounting Research 24 (2): 412-21. https://doi.org/10.2307/2491145.

Ryan, Christine, Trevor Stanley, dan Morton Nelson. 2002. "Accountability disclosures by queensland local government councils: 1997-1999." Financial Accountability \& Management Journal 18 (3): 261-89. https://doi.org/10.1111/1468-0408.00153. 
Suliyanto. 2011. Ekonometrika Terapan: Teori dan Aplikasi dengan SPSS. Yogyakarta: Penerbit ANDI.

Zucker, L G. 1987. "Institutional theories of organization." Annual Review of Sociology 13: 443-64. https://doi.org/10.1146/annurev.so.13.080187.002303. 


\section{LAMPIRAN}

Tabel 1 Indikator Peringkat Emas

\begin{tabular}{l}
\hline Aspek \\
\hline Pencemaran Air \\
Pencemaran udara atau energ
\end{tabular}

Limbah B3

Padat non B3

Sistem manajemen lingkungan

Community Development
1. Mempunyai program kerja konservasi penggunaan air.

2. Melakukan audit penggunaan air secar berkala.

3. Mempunyai neraca penggunaan air untuk seluruh air yang digunakan.

4. Melakukan upaya recycle minimal $30 \%$ dari total air limbah yang dihasilkan berdasarkan baseline data.

1. Mempunyai programkonservasi energi dan pengurangan emisi udara.

2. Melakukan audit penggunaan energi dan pengendalian emisi udara.

3. Mempunyai neraca penggunaan energi.

4. Melakukan kegiatan pengurangan emisi fugitive minimal $20 \%$ dari baseline data.

5. Melakukan kegiatan pengurangan penggunaan BPO (Bahan Perusak Ozon).

6. Melakukan kegiatan pengurangan GRK sebesar minimal 5\% dari baseline data.

7. Melakukan efisiensi energi minimal $5 \%$ dari baseline data.

1. Mempunyai program 3R (Reuse, Recycle, Recovery) untuk pengolahan limbah B3.

2. Melakukan upaya 3R minimal $30 \%$ dari total limbah yang berpotensi untuk dilakukan 3R selama periode penilaian berdasarkan baseline data.

1. Mempunyai program 3R kegiatan pengolahan limbah non B3.

2. Melakukan upaya 3R minimal $30 \%$ dari total limbah padat non B3 yang berpotensi untuk dilakukan 3R berdasarkan baseline data.

1. Melakuakn audit lingkungan secara keseluruhan berskala.

2. Memperoleh sertifikasi system manajemen lingkungan (SML) dari lembaga akreditasi lebih dari satu kali.

3. Telah mendapatkan peringkat PROPER hijau selama dua kali berturut-turut.

1. Melakukan upaya pemberdayaan masyarakat sehingga dapat, mandiri, seperti adanya usaha mandiri masyarakat.

2. Mendapatkan penghargaan Corporate Social Responsibility (CSR) dari lembaga kredibel lainnya.

Sumber: Kementerian Lingkungan Hidup 
Tabel 2

Indikator Peringkat Hijau

\begin{tabular}{|c|c|}
\hline Aspek & Indikator \\
\hline \multirow[t]{4}{*}{ Pencemaran air } & 1. Melakukan audit penggunaan air. \\
\hline & $\begin{array}{l}\text { 2. Mempunyai neraca penggunaan air untuk seluruh air yang } \\
\text { digunakan. }\end{array}$ \\
\hline & $\begin{array}{l}\text { 3. Melakukan upaya } 3 \mathrm{R} \text { untuk air limbah minimal } 20 \% \text { dari } \\
\text { total air limbah yang dihasilkan berdasarkan baseline data. }\end{array}$ \\
\hline & 4. Melakukan upaya efisiensi penggunaan air. \\
\hline \multirow[t]{6}{*}{ Pencemaran udara atau energy } & $\begin{array}{l}\text { 1. Mempunyai program konservasi energi dan pengurangan } \\
\text { energi dan penggunaan emisi udara. }\end{array}$ \\
\hline & $\begin{array}{l}\text { 2. Melakukan audit penggunaan energi dan pengendalian } \\
\text { emisi udara. }\end{array}$ \\
\hline & 3. Mempunyai neraca penggunaan energi. \\
\hline & $\begin{array}{l}\text { 4. Melakukan kegiatan pengurangan emisi fugitive minimal } \\
2 \% \text { dari baseline data. }\end{array}$ \\
\hline & $\begin{array}{l}\text { 5. Melakukan kegiatan pengurangan penggunaan BPO } \\
\text { (Bahan Perusak Ozon). }\end{array}$ \\
\hline & $\begin{array}{l}\text { 6. Melakukan kegiatan pengurangan GRK sebesar minimal } \\
2 \% \text {. }\end{array}$ \\
\hline Limbah B3 & $\begin{array}{l}\text { 1. Melakukan upay } 3 \mathrm{R} \text { minimal } 20 \% \text { dari total limbah } \mathrm{B} 3 \\
\text { yangdihasilkan oleh perusahaan dan berpotensi untuk } \\
\text { dilakukan } 3 \mathrm{R} \text { selama periode penilaian. }\end{array}$ \\
\hline Padat non B3 & $\begin{array}{l}\text { 1. Melakukan upaya } 3 \mathrm{R} \text { total minimal } 20 \% \text { dari total limbah } \\
\text { non B3 yang berpotensi untuk dilakukan } 3 \mathrm{R} \text {. }\end{array}$ \\
\hline Manajemen & 1. Melakukan audit lingkungan secara keseluruhan. \\
\hline Lingkungan & $\begin{array}{l}\text { 2. Memiliki sertifikasi system manajemen lingkungan (SML) } \\
\text { oleh lembaga akreditasi atau lembaga lainnya. }\end{array}$ \\
\hline
\end{tabular}

Tabel 3

Indikator Peringkat Biru

\begin{tabular}{|c|c|}
\hline Aspek & Indikator \\
\hline Air & $\begin{array}{l}\text { 1. } 100 \% \text { data pemantauan memnuhi BMAL (Baku Mutu Air } \\
\text { Limbah). } \\
\text { 2. Menyampaikan } 100 \% \text { data pemantauan yang dipersyaratkan. } \\
\text { 3. Memenuhi seluruh ketentuan teknis lainnya yang } \\
\text { dipersyaratkan. }\end{array}$ \\
\hline AMDAL & $\begin{array}{l}\text { 1. Melaksanakan dan melaporkan pelaksanaan RKL/RPL atau } \\
\text { UKL/UPL sesuai dengan ketentuan dan persyaratkan } \\
\text { AMDAl. }\end{array}$ \\
\hline \multirow[t]{4}{*}{ Udara } & $\begin{array}{l}\text { 1. Bagi sumber emisi yang berjumlah } \leq 5 \text { cerobong, semua } \\
\text { cerobong harus dilakukan pemantauan. } \\
\text { 2. Bagi sumber emisi yang berjumlah, } 5 \text { cerobong dapat } \\
\text { dilakukan pemantauan minimal } 80 \% \text { dari jumlah total } \\
\text { cerobong. }\end{array}$ \\
\hline & $\begin{array}{l}\text { 3. Bagi yang memiliki baku mutu emisi spesifik semua } \\
\text { parameter dipantau, sedangkan yang tidak memiliki baku } \\
\text { mutu emisi spesifik dipilih } 3 \text { parameter yang dominan. }\end{array}$ \\
\hline & $\begin{array}{l}\text { 4. Menyampaikan } 100 \% \text { data pemantauan yang dipersyaratkan. } \\
\text { 5. } 100 \% \text { data pemantauan memenuhi BMEU yang } \\
\text { dipersyaratkan. }\end{array}$ \\
\hline & $\begin{array}{l}\text { 6. Memenuhi seluruh ketentuan teknis lainnya yang } \\
\text { dipersyaratkan. }\end{array}$ \\
\hline
\end{tabular}




\begin{tabular}{ll}
\hline Limbah B3 & 1. $\begin{array}{l}\text { Memenuhi } \geq 90 \% \text { ketentuan pengelolaan limbah B3 yang } \\
\text { wajib dilakukan sesuai dengan izin dimiliki oleh perusahaan. }\end{array}$ \\
2. & $\begin{array}{l}\text { Kinerja PLB3 } \geq 90 \% \text { dari total LB3 yang dihasilkan yang } \\
\text { tercatat dalam neraca limbah B3. }\end{array}$ \\
3. $\begin{array}{l}\text { Telah menyelsaikan upaya clean-up open dumping dan open } \\
\text { burning dan atau upaya lanjut yang telah disetujui oleh KLH. } \\
\text { 4. }\end{array}$ & Melakukan upaya 3R. \\
\hline
\end{tabular}

Tabel 4

Indikator Peringkat Merah

\begin{tabular}{|c|c|}
\hline Aspek & Indikator \\
\hline AMDAL & $\begin{array}{l}\text { 1. Melaksanakan }<50 \% \text { kegiatan pengelolaan } \\
\text { lingkungan sesuai dengan ketentuan dan } \\
\text { persyaratan dalam AMDAL. }\end{array}$ \\
\hline Air & $\begin{array}{l}\text { 1. < 50\% data emantauan memnuhi BMAL yang } \\
\text { dipersyaratkan. } \\
\text { 2. Menyampaikan }<50 \% \text { data penyampaian yang } \\
\text { dipersyaratkan. } \\
\text { 3. Memenuhi < } 50 \% \text { ketentuan teknis lainnya yang } \\
\text { dipersyaratkan. }\end{array}$ \\
\hline Udara & $\begin{array}{l}\text { 1. Pemantauan dilakukan } \leq 3 \text { cerobong. } \\
\text { 2. Bagi sumber emisi yang berjumlah } \geq 5 \text { cerobong } \\
\text { dilakukan pemantauan minimal } \leq 30 \% \text { dari jumlah } \\
\text { total cerobong. }\end{array}$ \\
\hline & $\begin{array}{l}\text { 3. Memantau } 50 \% \text { parameter dari baku mutu emisi } \\
\text { spesifik dipantau } \leq 2 \text { parameter yang dominan. } \\
\text { 4. Menyampaikan } \leq 50 \% \text { data pemantauan yang } \\
\text { dipersyaratkan. } \\
\text { 5. } \leq 50 \% \text { data pemantauan memenuhi BMEU yang } \\
\text { dipersyaratkan. } \\
\text { 6. Memenuhi } \leq 50 \% \text { ketentuan teknis lainnya yang } \\
\text { dipersyaratkan. }\end{array}$ \\
\hline Limbah B3 & $\begin{array}{l}\text { 1. Memenuhi } \leq 40 \% \text { ketentuan pengelolaan limbah } \\
\text { B3 yang wajib dilakukan sesuai dengan izin yang } \\
\text { dimiliki oleh perusahaan. } \\
\text { 2. Kinerja PLB3 } \leq 40 \% \text { dari total limbah B3 yang } \\
\text { dihasilkan dengan tercatat dalam neraca LB3. } \\
\text { 3. Sudah menghentikan open dumping dan open } \\
\text { burning. } \\
\text { 4. Tidak memiliki izin pengelolaan limbah B3 dan } \\
\text { atau menyerahkan limbah B3 ke pihak ke-3 yang } \\
\text { tidak memiliki izin. } \\
\text { 5. Telah melakukan usaha pengelolaan limbah B3 ke } \\
\text { pihak ke-3 yang tidak memiliki izin. }\end{array}$ \\
\hline
\end{tabular}

Sumber: Kementerian Lingkungan Hidup

Tabel 5

Indikator peringkat hitam

\begin{tabular}{lll}
\hline & Aspek & \multicolumn{1}{c}{ Indikator } \\
\hline AMDAL & 1. & Tidak memiliki AMDAL yang telah disetujui \\
& oleh komisi AMDAL.
\end{tabular}


sekali.

3. Melakukan by pass untuk pembuangan air limbah dengan sengaja.

4. Melakukan by pass lebih dari satu kali.

Udara

1. Tidak melakukan pemantauan emisi cerobong sama sekali.

2. $50 \%$ data pemantauan yang wajib disampaikan melebihi 500\% BMEU.

Limbah B3

1. Melakukan kegiatan open dumping dan atau open burning limbah B3 dengan sengaja secara langsung ke lingkungan dan tidak melakukan upaya sama sekali.

Sumber: Kementerian Lingkungan Hidup 
Volume 19 No. 3, Desember 2016

ISSN 1979 - 6471 